\title{
QUALITY EVALUATION OF ZOBO TEA FLAVOURED WITH CLOVE AND GINGER PACKED IN TEA BAGS
}

\section{Nwankwo Chibuzo S. ${ }^{1}$, Edozie Precious C. ${ }^{2}$, Okpomor Endurance O. ${ }^{3}$, Mbachiantim James T. ${ }^{4}$, Okoyeuzu Chigozie F. ${ }^{5}$, Carew Irene E. ${ }^{6}$, Belay Dereje $^{7}$ and Abebe Teshome ${ }^{8}$}

${ }^{1}$ Department of Food Science and Technology, College of Food Technology and Human Ecology, Federal University of Agriculture Makurdi.

E-mail: toteupstar@yahoo.com

${ }^{2}$ Department of Food Science and Technology, College of Food Technology and Human Ecology, Federal University of Agriculture Makurdi.

${ }^{3}$ International Centre for Biotechnology (ICB) under the Auspices of UNSCO, at the University of Nigeria, Nsukka

${ }^{4}$ Department of Nutrition and Dietetics, College of Food Technology and Human Ecology, Federal University of Agriculture Makurdi

${ }^{5}$ Department of Food Science and Technology, Faculty of Agriculture, University of Nigeria Nsukka

${ }^{6}$ Department of Food Science and Technology, College of Food Technology and Human Ecology,

Federal University of Agriculture Makurdi.

${ }^{7}$ Department Food Process Engineering, College of Engineering and Technology, Wolkite University Ethiopia.

${ }^{8}$ Department of Chemical Engineering, Kombolcha Institute of Technology, Wollo University, Wollo, Ethiopia

Cite this article:

Nwankwo C.S., Edozie P.C., Okpomor E.O., Mbachiantim J.T., Okoyeuzu C.F., Carew I.E., Belay D., Abebe T. (2022), Quality Evaluation of Zobo Tea Flavoured with Clove and Ginger Packed in Tea Bags. African Journal of Agriculture and Food Science 5(1), 1-10. DOI: 10.52589/AJAFS4VSOSMK5.

\section{Manuscript History}

Received: 18 Dec 2021

Accepted: 12 Jan 2022

Published: 3 Feb 2022

Copyright $\left({ }^{\circ} 2022\right.$ The Author(s). This is an Open Access article distributed under the terms of Creative Commons AttributionNonCommercial-NoDerivatives 4.0 International (CC BY-NC-ND 4.0 ), which permits anyone to share, use, reproduce and redistribute in any medium,

1 provided the original author and source are credited.
ABSTRACT: The nutritional quality of zobo tea flavoured with clove and ginger was assessed. One-way analysis of variance was applied to the data generated. Dehydrated sorrel calyx (zobo) was crushed and mixed with cloves and ginger to produce four different blends of zobo tea in teabags. The moisture of four different blends of the tea ranges from $9.41 \%$ - $11.46 \%$. The ash, vitamin $B 9$, and calcium content of $100 \%$ zobo tea were significantly $(p<0.05)$ higher than others, while the iron content of $80 \%$ zobo and $20 \%$ clove tea were significantly $(p<0.05)$ higher than others. The fibre and pro-vitamin A content of $80 \%$ zobo, $10 \%$ ginger, and $10 \%$ clove tea were significantly $(p<0.05)$ higher than the others. Plate bacteria, coliform and fungal counts of the zobo tea ranged from $1.25 \times 104$ to $1.10 \times 1.107 \mathrm{cfu} / \mathrm{ml}$. In terms of taste, colour, flavour and general acceptability, the panellists showed significantly $(p<0.05)$ more preference for $80 \%$ zobo, $10 \%$ ginger and $10 \%$ clove tea. Zobo tea can be produced commercially, preserved for longer periods, and attract acceptance if processed with natural spices and packaged in tea bags; it will also be available and accessible at all times.

KEYWORDS: Zobo, Clove, Ginger, Flavor, Tea begs 


\section{INTRODUCTION}

Rosell (Hibiscus sabdariffa) dried calyces are tropical and semi-tropical annual herbs found in both the tropics and subtropics. It is processed into zobo drink, which contains carbohydrates, fibre, calcium, iron, beta-carotene, vitamin $\mathrm{C}$, and phytochemicals (Adelekan et al., 2013). Due to nutritional degradation spoilage induced by spoilage bacteria in the drink, the short shelf-life of zobo drinks limits their health sustainability (Obi, 2015). The short shelf life of zobo at room temperature immediately after production is a major barrier to mass production and commercialization. This is because zobo drinks can naturally ferment if left unpreserved due to microbial activity, making the drink a potential health hazard if consumed. (Ukwuru and Uzodimma, 2010; Braide et al., 2012; Obi, 2015).

The majority of producers rely significantly on preservatives. Several spices, like garlic, ginger, and clove, have been recognized and used for ages, especially for their aroma and, to a lesser extent, for their preservation qualities (Izah et al., 2016). Garlic, cinnamon, and cloves have also been shown to inhibit bacterial and mould growth (Adesokan et al., 2013; Izah et al., 2016; Adeoye et al., 2019). The use of inexpensive, widely accessible, and generally underutilized indigenous spices as an ingredient in zobo beverages would improve the taste while also extending the shelf life (Egbere et al., 2007; Izah et al., 2016). Unfortunately, natural spices have a shelf life of 48-72 hours after manufacture if not refrigerated (Bamishaiye et al., 2011; Lawal et al., 2014; Izah et al., 2016; Adeoye et al., 2019). The shelf life of the zobo drink was increased between 4-14 days using chemical preservatives such as sodium benzoate, sorbate, propionate, and acetic acid. However, the shelf life is insufficient for large-scale manufacture (Egbere et al., 2007; Braide et al., 2012; Izah et al., 2016).

Consequently, if zobo is flavoured with natural spices, processed into water-soluble dry form, and packaged in tea bags, it may be manufactured on a large scale, stored for longer periods, keep its nutritional value, and gain acceptance (Mohammed et al., 2017). This will also make it available, easier and accessible anytime needed to prepare since it can be reconstituted with hot water, and for convenience since it is lightly portable and can be carried along anywhere since it is in a dried form. The flavoured zobo tea in the tea bag can be dipped in hot water for a couple of minutes and drunk as hot zobo tea or a cold zobo drink when allowed to cool or refrigerate. This is recommended if the preservation and packaging method of zobo drink is to be improved and a longer shelf life of zobo drink nutrients is desired, which is costeffective and can increase its commercial potential by allowing its sale outside of its production area (Mohammed et al., 2017). As a result, by making the drink widely available in Sub-Saharan African countries, more people may benefit from its nutritional value and the zobo tea will become more cost-effective due to its extended shelf life. Rather than choosing to buy artificial soft drinks or going through the stress of preparing a healthy zobo, a cup of freshly boiled water and a teabag of flavoured zobo with all of the ingredients in the proper proportions will provide a pleasant zobo experience. However, the study aimed to evaluate the nutritional quality and sensory characteristics of zobo tea bags flavoured with clove and ginger. 


\section{MATERIALS AND METHODS}

\section{Materials}

Hibiscus sabdariffa (the dark red variety), dried cloves and fresh ginger were obtained from the open North-bank market in Makurdi, Benue State, Nigeria.

\section{Methods}

\section{Preparation of flavoured zobo tea and nutritional analysis}

The dark purple sorrel calyx was separated by winnowing, cleaned, de-stemmed, and weighed $(1000 \mathrm{~g})$ in a stainless steel jar with $500 \mathrm{ml}$ of potable water. This was infused by heating a steam jacketed kettle at $72{ }^{\circ} \mathrm{C} \pm 2{ }^{\circ} \mathrm{C}$ for 90 minutes, followed by dehydrated at 72 ${ }^{\circ} \mathrm{C} \pm 2{ }^{\circ} \mathrm{C}$ for $5 \mathrm{hrs}$ and $45 \mathrm{mins}$ (Mohammed et al., 2017). The calyces were crushed to a mesh size of 200 microns after drying. These tea-sized particles were then placed in an airtight vessel to be fortified with additives before being packaged. The crushed dried sorrel calyx (zobo) was mixed with ground cloves and ginger to produce four distinct blends of zobo tea packed in tea bags, such as $100 \%$ zobo (Z), $80 \%$ zobo and $20 \%$ clove (ZC), $80 \%$ zobo and $20 \%$ ginger (ZG), and (80) zobo, (10\%) ginger and (10\%) clove (ZGC) as shown in Table 1. Three grams $(3 \mathrm{~g})$ of each formulation were poured into tea bags. According to Joseph and Adogbo (2015), the extraction rate is more proportionately dependent on the amount of calyx (zobo), and a $2.0 \mathrm{~g}$ sample produced the best extraction at a constant temperature. Four sets of twenty tea bags were manufactured and packaged in the same manner before being placed in a cardboard box. This was then sealed with polythene to prevent moisture from passing through (Figure 1). The physicochemical characteristics, microbial analysis, and sensory evaluation scores of the four different blends of zobo tea were determined (Iwe, 2002; AOAC, 2010).

\section{Statistical Analysis}

All measures were tested in triplicate, and the resulting data were analyzed using one-way ANOVA (ANOVA). The Duncan multiple range test (SAS version 9.3) was used to separate means, and experimental results were reported as means $\pm \mathrm{SD}$.

Table 1: Blend formulation of flavoured zobo tea

\begin{tabular}{cccc}
\hline Sample & Zobo (\%) & Clove (\%) & Ginger (\%) \\
\hline Z & 100 & 0 & 0 \\
\hline ZG & 80 & 20 & 0 \\
\hline ZC & 80 & 0 & 20 \\
\hline ZCG & 80 & 10 & 10 \\
\hline
\end{tabular}

$100 \%$ zobo $=\mathrm{Z}, 80 \%$ zobo and $20 \%$ clove $=\mathrm{ZC}, 80 \%$ zobo and $20 \%$ ginger $=\mathrm{ZG}$, and (80) zobo, $(\mathbf{1 0 \%})$ ginger and $(\mathbf{1 0 \%})$ clove $=\mathrm{ZGC}$ 


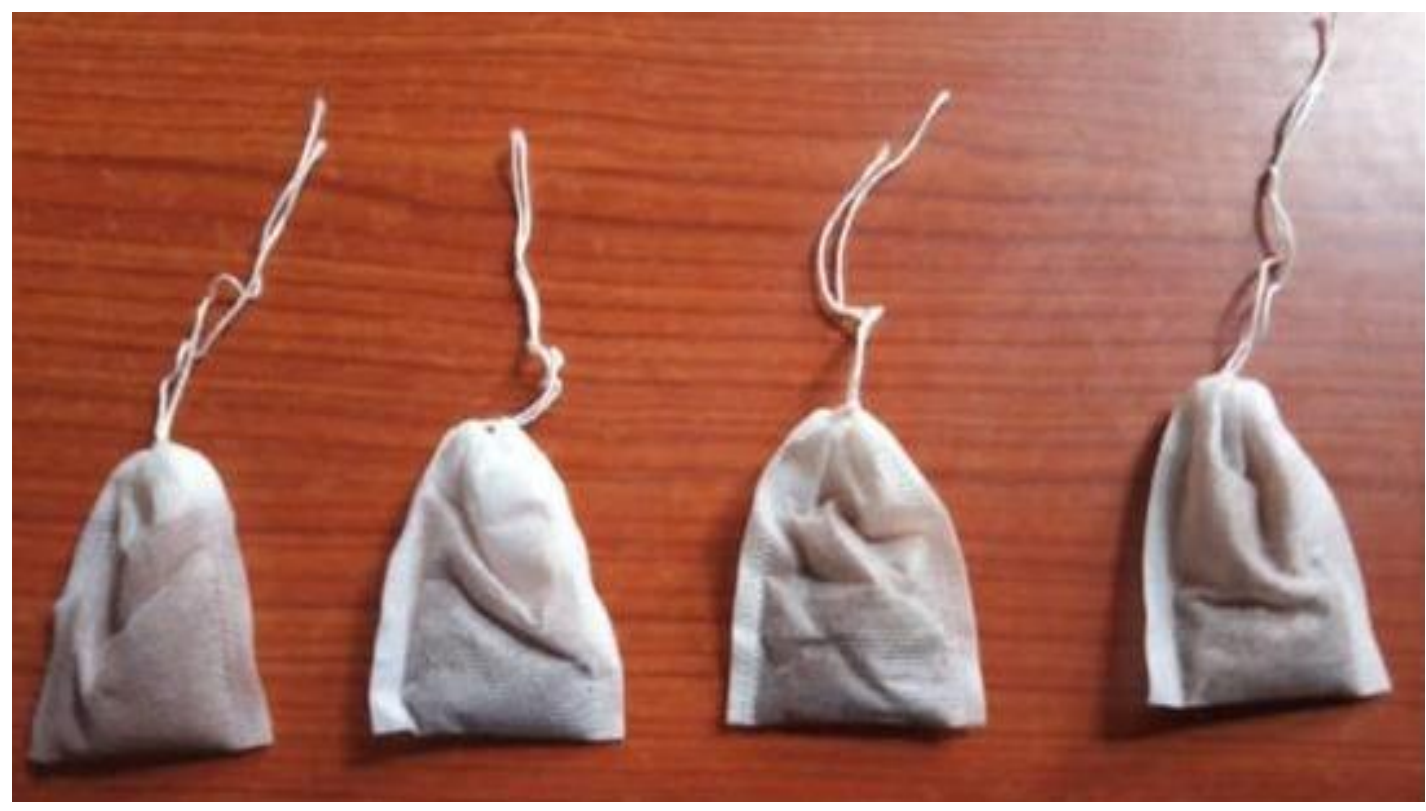

Figure 1: Flavoured zobo tea packaged in tea bag

\section{RESULTS AND DISCUSSION}

\section{Physico-chemical properties of flavoured zobo tea}

The result in Table 2 shows that the moisture of the flavoured zobo tea ranged from $9.41-$ $11.46 \%$, indicating that the flavoured zobo tea has a low moisture content and, if properly packaged, could have a longer shelf-life than the zobo drink, which deteriorates within 24 hours due to fermentation (Mohammed et al., 2017). This is contrary to Mohammed et al. (2017), who reported lower moisture content. The fat content of ZG tea $(1.21 \%)$ was significantly $(p<0.05)$ higher than the others. Babalola and Aworh, (2001) discovered that the zobo leaves contain about $3 \%$ fat before preparation, and in the water in which the leaves are boiled, fat does not dissolve easily. Therefore, the finished product should be low in fat. The low-fat content of calyces flavoured with natural spices could explain why obese people drink roselle drinks (Salami and Afolayan, 2021). Awe and Abdulmumini (2019) reported a similar result $(1.56 \%)$ when they assessed the effect of different preservatives on the microbial load of zobo drink. Though dietary fat enhances food palatability through absorption and taste retention, the low-fat level found suggests that drinking zobo tea may be appropriate for those interested in weight control as well as illness prevention associated with high dietary fat intake (Salami and Afolayan, 2021). The protein (9.64\% and 9.62\%) and ash $(8.81 \%$ and $8.74 \%)$ contents of $\mathrm{Z}$ and $\mathrm{ZC}$ tea were significantly $(p<0.05)$ higher than others, while the carbohydrate $(63.90 \%)$ content of ZC tea was significantly $(p<0.05)$ higher than others. Meanwhile, the fibre content of ZCG tea was significantly $(p<0.05)$ higher than others. Similar results were reported by Mohammed et al. (2017). Mohammed et al. (2017) also reported an appreciable amount of protein $(7.44 \%)$, carbohydrates $(83.32 \%)$ and fibre $(7.44 \%)$ in instant sorrel (zobo) drinks made by infusion, dehydration, and size reduction methods. A lower protein content (2.16\%) was reported by Awe and Abdulmumini (2019). Carbohydrates appear to be abundant in flavoured zobo tea. However, because this value was calculated rather than measured, it can only be used to estimate carbohydrate 
content. It was discovered that the protein, fat, and carbohydrate content were all high, especially in Z and ZC. Roselle is frequently touted as an energy candidate because it has fibre, and is used in beverages, edible foliage, and oilseed production. Roselle extract has been suggested for blood pressure reduction (Adebayo-tayo and Samuel, 2009). Every part of the plant contains high amounts of ash, which generally points to the fact that it contains quantities of minerals that are required by the body. Therefore, consumption of any part of the plant, including tea, could enhance the nutritional status of people in Nigeria and other third world countries (Mohammed et al., 2017). According to Mohammed et al. (2017), roselle has a high ash content, indicating that the plant contains a significant amount of minerals that the body requires. This could be due to lower moisture content and thus containing more dry matter (Akpanyung, 2005).

The pro-vitamin A content ranged from $461.00(\mathrm{mg} / 100 \mathrm{~g})$ to $470.30(\mathrm{mg} / 100 \mathrm{~g})$ with ZCG tea having significantly $(p<0.05)$ the highest pro-vitamin A content than others. The vitamin $\mathrm{B}_{9}$ content of $\mathrm{Z}$ tea was significantly $(p<0.05)$ higher than others. All the flavoured zobo teas had almost the same amount of vitamin $C$, which ranged from $15.76(\mathrm{mg} / 100 \mathrm{~g})$ to 15.91 (mg/100g). Adesokan et al. (2013), who investigated the quality attributes of Hibiscus sabdariffa (zobo) drinks blended with aqueous extracts of ginger and garlic, discovered a higher value of vitamin $\mathrm{C}(22.50-35.8 \mathrm{mg} / 100 \mathrm{~g})$ and concluded that blending with these spices can improve the vitamin $\mathrm{C}$ status of zobo beverages. The lower vitamin $\mathrm{C}$ content of roselle reported in this study could be attributed to nutritional losses during the drying and processing of the calyces into tea (Mohammed et al., 2017). According to Osueke and Ehirim (2004), vitamin $\mathrm{C}$ is water-soluble and easily lost during boiling, heating, and cooking. The potassium content of ZG tea was significantly $(p<0.05)$ higher than others. There was no significant $(p>0.05)$ difference in the magnesium content of the zobo tea, which ranged from $1.19(\mathrm{mg} / 100 \mathrm{~g})-1.00(\mathrm{mg} / 100 \mathrm{~g})$. The calcium content of $\mathrm{Z}$ tea was significantly $(p<0.05)$ higher than that of others. The iron content of ZC tea was significantly $(p<0.05)$ higher than that of others. Adesokan et al. (2013) reported a different (higher) result, but Adelekan et al. (2014) reported a similar result when they assessed the production and acceptability of fruitenhanced zobo drinks.

There was no significant $(p>0.05)$ difference in bulk density, water absorption capacity, and foam capacity. The bulk density of flour is determined by its particle size and initial moisture content. Water absorption capacity is commonly used to determine the number of polar groups on the protein's surface and their interaction with water molecules (Zhang et al., 2015). Large air bubbles surrounded by a thinner and less flexible protein film could result from high foaming ability. These air bubbles may be more easily collapsed, lowering the stability of the foam. (Jitngarmkusol et al., 2008). The ZC tea $(63.50 \mathrm{sec})$ was significantly ( $p$ $<0.05)$ wetter than others, followed by ZCG tea $(142.50 \mathrm{sec}), \mathrm{ZG}$ tea $(176 \mathrm{sec})$ and Z tea $(220.50 \mathrm{sec})$. 
Table 2: Physico-chemical composition of flavored zobo tea

\begin{tabular}{|c|c|c|c|c|c|}
\hline \multirow{2}{*}{$\begin{array}{l}\text { Physico-chemical } \\
\text { composition }\end{array}$} & \multicolumn{4}{|c|}{ Flavored zobo tea } & \multirow[b]{2}{*}{ LSD } \\
\hline & $\mathbf{Z}$ & $\mathbf{Z G}$ & $\mathbf{Z C}$ & ZCG & \\
\hline Moisture (\%) & $9.86^{\mathrm{bc}} \pm 0.2$ & $11.46^{\mathrm{a}}$ & $9.41^{b c}$ & $10.46^{\mathrm{ab}}$ & 1.24 \\
\hline & & \pm 0.06 & \pm 0.11 & \pm 0.02 & \\
\hline Protein (\%) & $9.64^{\mathrm{a}} \pm 0.6$ & $9.31^{\mathrm{c}} \pm 0.09$ & $\begin{array}{l}9.62^{\mathrm{ab}} \\
\pm 0.00\end{array}$ & $9.20^{\mathrm{d}} \pm 0.18$ & 0.10 \\
\hline Crude fat $(\%)$ & $0.26^{\mathrm{d}} \pm 0.53$ & $1.21^{\mathrm{a}} \pm 0.25$ & $0.64^{c} \pm 0.41$ & $0.96^{b} \pm 0.01$ & 0.09 \\
\hline Crude fibre (\%) & $6.11^{\mathrm{d}} \pm 0.48$ & $8.68^{c} \pm 0.2$ & $9.06^{\mathrm{b}} \pm 0.01$ & $9.20^{\mathrm{a}} \pm 0.00$ & 0.08 \\
\hline $\operatorname{Ash}(\%)$ & $8.81^{b} \pm 0.08$ & $8.16^{\mathrm{d}} \pm 0.12$ & $8.74^{\mathrm{a}} \pm 0.03$ & $8.47^{c} \pm 0.03$ & 0.07 \\
\hline Carbohydrate (\%) & $68.33^{\mathrm{b}} \pm 0.67$ & $\begin{array}{l}61.87^{\mathrm{d}} \\
\pm 0.41\end{array}$ & $63.90^{\mathrm{a}} \pm 05$ & $\begin{array}{l}62.96^{\mathrm{bc}} \\
\pm 0.17\end{array}$ & 0.45 \\
\hline $\begin{array}{l}\text { Pro-Vitamin } \\
\text { (mg/100g) }\end{array}$ & $\begin{array}{l}361.00^{\mathrm{d}} \\
\pm 0.53\end{array}$ & $\begin{array}{l}461.15^{c} \\
\pm 0.63\end{array}$ & $\begin{array}{l}470.30^{\mathrm{a}} \\
\pm 1.06\end{array}$ & $465.20^{\mathrm{b}} \pm 0.57$ & 0.50 \\
\hline Vitamin C (mg/100g) & $\begin{array}{l}13.90^{\mathrm{c}} \\
\pm 0.79\end{array}$ & $\begin{array}{l}15.91^{\mathrm{a}} \\
\pm 0.53\end{array}$ & $\begin{array}{l}15.76^{\mathrm{b}} \\
\pm 0.63\end{array}$ & $15.85^{\mathrm{a}} \pm 052$ & 0.07 \\
\hline Vitamin $B_{9}(\mathbf{m g} / \mathbf{1 0 0 g})$ & $\begin{array}{l}301.05^{\mathrm{a}} \\
\pm 0.53\end{array}$ & $\begin{array}{l}298.34^{\mathrm{b}} \\
\pm 042\end{array}$ & $\begin{array}{l}295.21^{\mathrm{d}} \\
\pm 1.03\end{array}$ & $\begin{array}{l}297.56^{\mathrm{bc}} \\
\pm 031\end{array}$ & 1.13 \\
\hline Potassium (mg/100g) & $5.11^{\mathrm{d}} \pm 0.02$ & $7.61^{\mathrm{a}} \pm 0.00$ & $7.13^{\mathrm{c}} \pm 0.01$ & $7.34^{b} \pm 0.01$ & 0.12 \\
\hline $\begin{array}{l}\text { Magnesium } \\
\text { (mg/100g) }\end{array}$ & $1.19^{\mathrm{a}} \pm 0.01$ & $1.01^{\mathrm{a}} \pm 0.01$ & $1.00^{\mathrm{a}} \pm 0.01$ & $1.04^{\mathrm{a}} \pm 0.01$ & - \\
\hline Calcium (mg/100g) & $0.92^{\mathrm{a}} \pm 0.00$ & $0.64^{\mathrm{d}} \pm 0.01$ & $0.72^{b} \pm 0.01$ & $0.70^{\mathrm{bc}} \pm 0.01$ & 0.03 \\
\hline Iron (mg/100g) & $1.35^{\mathrm{d}} \pm 0.01$ & $1.42^{\mathrm{c}} \pm 0.01$ & $1.82^{\mathrm{a}} \pm 0.00$ & $1.79^{\mathrm{ab}} \pm 0.00$ & 0.05 \\
\hline Bulk density (g/m) & $0.60^{\mathrm{a}} \pm 0.00$ & $0.60^{\mathrm{a}} \pm 0.00$ & $0.59^{\mathrm{a}} \pm 0.00$ & $0.58^{\mathrm{a}} \pm 0.00$ & - \\
\hline WAC (ml/g) & $3.45^{\mathrm{a}} \pm 0.07$ & $3.20^{\mathrm{a}} \pm 0.00$ & $3.40^{\mathrm{a}} \pm 0.00$ & $3.30^{\mathrm{a}} \pm 0.28$ & - \\
\hline Foam capacity (\%) & $\begin{array}{l}12.50^{\mathrm{a}} \\
\pm 0.71\end{array}$ & $\begin{array}{l}15.50^{\mathrm{a}} \\
\pm 0.71\end{array}$ & $\begin{array}{l}13.00^{\mathrm{a}} \\
\pm 1.14\end{array}$ & $12.50^{\mathrm{a}} \pm 0.79$ & - \\
\hline Wettability (sec) & $\begin{array}{l}220.50^{\mathrm{a}} \\
\pm 0.71 \\
\end{array}$ & $\begin{array}{l}176.00^{\mathrm{b}} \\
\pm 1.41 \\
\end{array}$ & $\begin{array}{l}63.50^{\mathrm{d}} \\
\pm 2.12 \\
\end{array}$ & $\begin{array}{l}142.50^{\mathrm{c}} \\
\pm 3.54 \\
\end{array}$ & 5.83 \\
\hline
\end{tabular}

Values are mean of duplicate determination with \pm standard deviation. Means in the same row with different superscripts are significantly $(\mathbf{p}<0.05)$. WAC $=$ Water absorption capacity. $100 \%$ zobo $=\mathrm{Z}, 80 \%$ zobo and $20 \%$ clove $=\mathrm{ZC}, 80 \%$ zobo and $20 \%$ ginger $=\mathbf{Z G}$, and $(\mathbf{8 0}) \mathrm{zobo},(\mathbf{1 0 \%})$ ginger and $(\mathbf{1 0 \%})$ clove $=\mathrm{ZGC}$ 


\section{Microbiological analysis of flavoured zobo tea}

Table 3 shows that the plate bacteria count was decreasing in all the samples. The plate bacteria count in ZCG tea was significantly $(p<0.05)$ higher than other teas throughout the three days. Adesokan et al. (2013) reported similar results, reporting that spices reduced the microbial loads of zobo samples during the seven-day storage. The plate coliform count decreased in Z and ZCG tea throughout the three days, but ZCG tea was significantly ( $p<$ $0.05)$ higher in plate bacteria count than the others. There was no plate coliform count in ZG tea on the first day and in ZC tea on the second day. There was a $1.78 \times 10^{4} \mathrm{cfu} / \mathrm{ml}$ and a 1.75 x $10^{5} \mathrm{cfu} / \mathrm{ml}$ plate coliform count in ZG tea and a 1.40 x $10^{5} \mathrm{cfu} / \mathrm{ml}$ plate coliform count in ZC tea, respectively. Similar results were reported by Adebayo-Tayo and Samuel (2009). This could be due to the addition of spices and low moisture content, which were able to reduce the microbial loads of zobo tea (Adesokan et al., 2013). The plate fungal count was decreasing in $\mathrm{ZC}$ tea and increasing in ZCG tea throughout the three days, but the plate bacteria count in ZC tea was significantly $(p<0.05)$ higher than the others. There was no plate coliform count in $\mathrm{Z}$ tea and $\mathrm{ZG}$ tea on the first and second day. On the third day, there was $1.2 \times 10^{5} \mathrm{cfu} / \mathrm{ml}$ and $1.90 \times 10^{5} \mathrm{cfu} / \mathrm{ml}$ plate fungal count, respectively. This could be attributed to the high spice concentration. There is evidence of increased antimicrobial activity associated with high spice concentrations (Ekeke et al., 2015).

Table 3: Microbiological analysis of flavored zobo tea

\begin{tabular}{|c|c|c|c|c|c|}
\hline \multirow{2}{*}{\multicolumn{2}{|c|}{ Microbial analysis }} & \multirow[t]{2}{*}{ Sample code } & \multicolumn{3}{|c|}{ Storage days } \\
\hline & & & Day 1 & Day 2 & Day 3 \\
\hline $\begin{array}{l}\text { Plate bacteria } \\
(\mathrm{cfu} / \mathrm{ml})\end{array}$ & count & $\begin{array}{c}\mathrm{Z} \\
\mathrm{ZG} \\
\mathrm{ZC} \\
\mathrm{ZCG}\end{array}$ & $\begin{array}{l}1.14 \times 10^{6 \mathrm{~d}} \\
1.22 \times 10^{6 \mathrm{c}} \\
1.41 \times 10^{5 \mathrm{~b}} \\
1.42 \times 10^{6 \mathrm{a}}\end{array}$ & $\begin{array}{l}1.11 \times 10^{6 a} \\
1.12 \times 10^{6 a} \\
1.18 \times 10^{5 c} \\
1.40 \times 10^{5 b}\end{array}$ & $\begin{array}{l}1.01 \times 10^{6 \mathrm{~b}} \\
1.07 \times 10^{6 \mathrm{~b}} \\
1.17 \times 10^{5 \mathrm{c}} \\
1.10 \times 10^{7 \mathrm{a}}\end{array}$ \\
\hline $\begin{array}{l}\text { Plate coliform } \\
(\mathrm{cfu} / \mathrm{ml})\end{array}$ & count & $\begin{array}{c}\mathrm{Z} \\
\mathrm{ZG} \\
\mathrm{ZC} \\
\mathrm{ZCG}\end{array}$ & $\begin{array}{c}1.31 \times 10^{4 \mathrm{~b}} \\
- \\
- \\
1.6 \times 10^{6 \mathrm{a}}\end{array}$ & $\begin{array}{c}1.25 \times 10^{4 \mathrm{c}} \\
1.78 \times 10^{4 b} \\
- \\
1.90 \times 10^{5 \mathrm{a}}\end{array}$ & $\begin{array}{l}1.14 \times 10^{5 c} \\
1.75 \times 10^{5 a} \\
1.40 \times 10^{5 c} \\
1.60 \times 10^{5 b}\end{array}$ \\
\hline $\begin{array}{l}\text { Plate fungal } \\
(\mathrm{cfu} / \mathrm{ml})\end{array}$ & count & $\begin{array}{c}\mathrm{Z} \\
\mathrm{ZG} \\
\mathrm{ZC} \\
\mathrm{ZCG}\end{array}$ & $\begin{array}{c}- \\
- \\
3.1 \times 10^{4 \mathrm{~b}} \\
2.67 \times 10^{6 \mathrm{a}}\end{array}$ & $\begin{array}{c}- \\
- \\
2.3 \times 10^{5 \mathrm{a}} \\
2.3 \times 10^{5 \mathrm{a}}\end{array}$ & $\begin{array}{l}1.2 \times 10^{5 \mathrm{~b}} \\
1.9 \times 10^{5 \mathrm{c}} \\
2.1 \times 10^{5 \mathrm{a}} \\
2.0 \times 10^{5 \mathrm{a}}\end{array}$ \\
\hline
\end{tabular}

Values are mean of duplicate determination. Means in the same row with different superscripts are significantly $(\mathrm{p}<0.05) .100 \%$ zobo $=\mathrm{Z}, 80 \%$ zobo and $20 \%$ clove $=\mathrm{ZC}$, $80 \%$ zobo and $20 \%$ ginger $=\mathrm{ZG}$, and $(80)$ zobo, $(10 \%)$ ginger and $(10 \%)$ clove $=\mathbf{Z G C}$. 


\section{Sensory characteristics of flavoured zobo tea}

The result in Table 4 shows the sensory characteristics of flavoured zobo tea. Significant differences $(\mathrm{p}<0.05)$ were observed in the taste, colour, flavour, and overall acceptability of the zobo tea blends. A similar result was reported by Popoola et al. (2019), who assessed the sensory characteristics of zobo drinks spiced with different spices. The panellists showed significantly $(\mathrm{p}<0.05)$ more preference in terms of taste, colour, flavour, and overall acceptability for ZCG tea, followed by ZC tea in terms of taste and colour. A similar result was reported by Adesokan et al. (2013), where they reported that the sensory attributes of the zobo samples containing spices were enhanced. Furthermore, the panellists' ratings indicate that flavoured zobo tea is likely to be acceptable by the general population if prepared with gloves and ginger. The popular choice of ginger and garlic may be attributed to the fact that they are commonly utilized in most Nigerian households (Popoola et al., 2019).

Table 4: Sensory characteristics of flavored zobo tea

\begin{tabular}{|c|c|c|c|c|c|}
\hline \multirow{2}{*}{$\begin{array}{l}\text { Sensory } \\
\text { characteristics }\end{array}$} & \multicolumn{4}{|c|}{ Flavored zobo tea } & \multirow{2}{*}{$\begin{array}{l}\text { LS } \\
\text { D }\end{array}$} \\
\hline & $\mathrm{Z}$ & $\mathrm{ZG}$ & ZC & ZCG & \\
\hline \multirow[t]{2}{*}{ Taste } & $6.00^{c}$ & $6.30^{c}$ & $7.93^{\mathrm{a}}$ & $7.50^{\mathrm{ab}}$ & 0.8 \\
\hline & \pm 0.02 & \pm 0.00 & \pm 0.01 & \pm 0.01 & 8 \\
\hline \multirow[t]{2}{*}{ Colour } & $7.20^{\mathrm{bc}}$ & $6.60^{b}$ & $7.70^{\mathrm{a}}$ & $7.70^{\mathrm{a}}$ & 0.9 \\
\hline & \pm 0.01 & \pm 0.01 & \pm 0.01 & \pm 0.01 & 5 \\
\hline \multirow[t]{2}{*}{ Flavor } & $6.70^{c}$ & $7.10^{\mathrm{b}}$ & $6.70^{c}$ & $7.30^{\mathrm{a}}$ & 0.1 \\
\hline & \pm 0.00 & \pm 0.01 & \pm 0.01 & \pm 0.01 & 1 \\
\hline \multirow[t]{2}{*}{ Over Acceptability } & $6.80^{\mathrm{ab}}$ & $7.10^{\mathrm{ab}}$ & $6.00^{c}$ & $7.50^{\mathrm{a}}$ & 0.8 \\
\hline & \pm 0.01 & \pm 0.01 & \pm 0.00 & \pm 0.00 & 3 \\
\hline
\end{tabular}

Values are mean of duplicate determination with \pm standard deviation. Means in the same row with different superscripts are significantly $(\mathbf{p}<0.05) .100 \%$ zobo $=\mathbf{Z}, \mathbf{8 0 \%}$ zobo and $20 \%$ clove $=\mathrm{ZC}, \mathbf{8 0} \%$ zobo and $20 \%$ ginger $=\mathrm{ZG}$, and $(80)$ zobo, $(10 \%)$ ginger and $(\mathbf{1 0 \%})$ clove $=\mathrm{ZGC}$

\section{CONCLUSION}

The results of this study showed that the protein, carbohydrate, ash, and iron content of $80 \%$ zobo and $20 \%$ clove tea were significantly $(p<0.05)$ higher than others, while the fibre, provitamin $\mathrm{A}$, and magnesium content of $80 \%$ zobo, $10 \%$ ginger, and $10 \%$ clove tea were significantly $(p<0.05)$ higher than others. This showed that $80 \%$ zobo and $20 \%$ clove tea had significantly better nutritional composition than others, followed by $80 \%$ zobo, $10 \%$ ginger and $10 \%$ clove tea. The panellists showed significantly $(p<0.05)$ more preference for $80 \%$ zobo, $10 \%$ ginger, and $10 \%$ clove tea in terms of taste, colour, flavour, and overall acceptability. This study also shows that zobo tea can be produced commercially, preserved for longer periods due to low moisture content, still retain its nutritive value, and attract acceptance if processed with natural spices and packaged in tea bags. For convenience, it will be made available and accessible at any time. The plate bacteria, coliform and fungal counts of some zobo tea increased during three days of microbial analysis. However, there is a need for further study to ascertain the nutritional and microbial stability of flavoured zobo tea in teabags. 


\section{REFERENCES}

Adebayo-Tayo, B. C., \& Samuel, U. A. (2009). Microbial quality and proximate composition of dried Hibiscus sabdariffa calyxes in Uyo, Eastern Nigeria. Malaysian Journal of Microbiology, 5(1), 13-18.

Adelekan, A. O., Arisa, N. U., Alamu, A. E., Adebayo, Y. O., \& Popoola, G. J. T. (2014). Production and acceptability of fruits enhanced zobo drink. Food Science and Technology Letters, 5 (1), 46.

Adeoye B. K, Oyewole O. B, Idowu M. A, Ademuyiwa O, Obadina A. O, Adaramola F. B, Ani I. F., \& Ngozi E.O (2019). Protection against Oxidative Damage Properties of Hibiscus sabdariffa Drink (Zobo) and Added Natural Food Additives.European Journal of Scientific Research, 152 (2), 53 - 162.

Adesokan, I. A., Abiola, O.P., Adigun, M. O., \& Anifowose, O. A. (2013). Analysis of quality attributes of Hibiscus sabdariffa (Zobo) drinks blended with aqueous extract of ginger and garlic. African Journal of Food Science, 7(7), $174-177$.

Akpanyung, E. O. (2005). Proximate and mineral element composition of bouillon cubes produced in Nigeria. Pakistan Journal of Nutrition, 45 (5), 327 - 329.

Association of Official Analytical Chemists (AOAC) (2010). Official Methods of Analysis. 18th Edition, Revision 3, Association of Official Analytical Chemists, Washington DC.

Awe, S., \& Abdulmumini, S. A. (2019). Effect of Different Preservatives on Microbial Load of Zobo Drink and Molecular Characterization of its Bacterial Flora. Nigerian Journal of Microbiology, 33(2), 4678 - 4686.

Bamishaiye, E. L, Olayemi, F. F., \& Bamishaiye, O. M. (2011). Effects of boiling time on mineral and vitamin $\mathrm{C}$ content of three varieties of Hibiscus sabdarifadrink in Nigeria. World Journal of Agricultural Sciences, 7(1), 62 - 67.

Braide, W., Oranusi, S., \& Peter-Ikechukwu, A. I. (2012). Perspectives in the hurdle techniques in the preservation of a non-alcoholic beverage, Zobo. African Journal of Food Science and Technology, 3(2), $46-52$.

Egbere, O. J. Anuonye, J. C, Chollom, P. F., \& Okpara P.V. (2007) Effects of some preservation techniques on the quality and storage stability of zobo drink (A Nigerian, Non-alcoholic beverages from Hibiscus Sabariffa). Journal Food Technology, 5 (3), 225- 228.

Ekeke, I. C., Nkwocha, A. C., Kamen, F. L., Kamalu, C. I. O., \& Uzondu, F. N. (2015). Studies on optimal conditions for the preservation of 'zobo'drink. International Journal of Engineering and Management Research (IJEMR), 5 (6), 121-125.

Iwe, M. O (2002). Handbook of sensory methods and analysis. PROJOINT Communications Services Ltd, Enugu pp. 70-72.

Izah, S. C., Kigigha, L. T., Aseibai, E. R., Okowa, I. P., \& Orutugu, L. A. (2016). Advances in preservatives and condiments used in zobo (a food-drink) production. Biotechnological Research, 2 (3), 104 -119.

Jitngarmkusol S, Hongsuwankul J., \& Tananuwong K. Chemical composition, functional properties and microstructure of defatted macademice flours (2008). Food Chemistry, $110,23-30$.

Joseph, A. D. \& Adogbo, G. M. (2015). Processing and packaging of Hibiscus sabdariffa for the preservation of nutritional constituents. International. Journal of Scientific and Engineering Research, 6, 532 - 536. 
Lawal, T. O., Ogudo, B.U., Oyedemi, T. O., Bamidele, T. A. \& Adeniyi, B.A. (2014). Antibacterial potentials of three common spices against selected pathogens. Journal of Natural Sciences Research, 4 (18), 78 - 84.

Mohammed, S. F., Gimba, I. K., \& Bahago, E. J. (2017). Production and quality evaluation of instant sorrel (zobo) drink produced by infusion, dehydration and size reduction methods. Journal of Nutrition and Health Sciences, 4(2), 205.

Obi C. D. (2015): Assessment of the preservative effects of different local spices and their flavour acceptability in Hibiscus Sabdariffa Calyx drinks. International Journal of Agriculture and Rural Development. 18 (1), 2161 - 2165.

Osueke, J. C. \& Ehirim, F. N. (2004). Chemical, nutritional and sensory analysis of zobo drink (var sabdariffa) and selected soft drinks. Journal of Agriculture and Food Sciences, 2 (1), 21 - 24.

Popoola, O. O., Balogun, D. A., Bello, A. \& Odeh, E. S. (2019). Sensory Evaluation of Zobo Drink Spiced with Different Spices. Research Journal of Food Science and Quality Control 5 (1), $21-23$.

Salami, S. O., \& Afolayan, A. J. (2021). Evaluation of nutritional and elemental compositions of green and red cultivars of roselle: Hibiscus sabdariffa L. Scientific Reports, 11 (1), 1 $-13$.

Ukwuru, M. U., \& Uzodinma, C. C. (2010). Preservative effect of spices and their flavour acceptability in zobo drink. Nigerian Food Journal, 28 (2), 265 - 274

Zhang, Y., Chen, H., Zhang, N., \& Ma, L. (2015). Antioxidant and functional properties of tea protein as affected by the different tea processing methods. Journal of Food Science and Technology: 52 (2), 742 - 752. 